\title{
KASUGAMYCIN INFLUENCE ON BACTERIAL BLIGHT OF COFFEE AND ON GREEN COFFEE BEANS PHYSICOCHEMICAL QUALITY
}

\author{
Ronei Aparecido Barbosa ${ }^{1}$, Paula Tristão Santini², Luiz Roberto Guimarães Guilherme ${ }^{3}$
}

(Received: January 25, 2017; accepted: Thursday, April 6, 2017)

\begin{abstract}
Brazil stands out as the world's largest coffee exporter. However, in the cold and windy regions, such as the southern of Minas Gerais, have been undergoing attack of diseases, including the bacterial blight of coffee caused by the bacterium Pseudomonas syringae pv. garcae, which despite not having the same importance as the coffee leaf rust, is causing damages and losses to the coffee plantation. The control is mainly done through preventive measures such as installation of windbreaks. When bacterial blight of coffee is already installed, the chemical control is used with syrups of copper-based products and antibiotics. The aim of the present study was to verify the efficiency of the antibiotic kasugamycin associated with copper hydroxide in the control of bacterial blight of coffee and raw coffee beans quality. The experimental design was a randomized block with five treatments, four replicates and plots of 10 plants in the field where the treatments consisted of different concentrations of the kasugamycin: $0.0,250,500,750$ and $1000 \mathrm{~mL} \mathrm{ha}^{-1}$ added with $1.0 \mathrm{~L}$ copper hydroxide. The percent analysis was performed on the raw beans in order to verify their physical and chemical quality. The obtained results demonstrate that the solution is efficient in the control of bacterial blight of coffee as well as in the improvement of vegetative vigor and production, but does not influence the quality of raw coffee bean.
\end{abstract}

Index terms: Bactericidal, Coffea arabica L., Pseudomonas syringae pv. garcae.

\section{INFLUÊNCIA DE KASUGAMICINA NA MANCHA AUREOLADA DO CAFEEIRO E NA QUALIDADE FÍSICO-QUÍMICA DO GRÃO CRU}

RESUMO: O Brasil se destaca por ser o maior exportador mundial de café, no entanto nas regiões frias e expostas ao vento, como no Sul de Minas Gerais, vêm sofrendo com o ataque de doenças, como bacteriose chamada Mancha Areolada causada pela bactéria Pseudomonas syringae pv. garcae Amaral que embora não tenha a mesma importância da ferrugem alaranjada vem causando danos e perdas a cafeicultura. $\mathrm{O}$ controle se dá principalmente por medidas preventivas, como a instalação de quebra-ventos, quando já instalada a bacteriose o controle químico é utilizado com caldas de produtos à base de cobre e antibióticos. O objetivo do trabalho foi verificar a eficiência do antibiótico kasugamicina associado com hidróxido de cobre no controle da mancha aureolada e na qualidade dos grãos cru de café. O delineamento experimental utilizado foi em blocos casualizados com 5 tratamentos, 4 repetições e parcelas de 10 plantas no campo onde os tratamentos constaram de diferentes concentrações do bactericida kasugamicina: 0,0;250, 500, 750 e $1000 \mathrm{~mL}$ ha-1 adicionados de 1,0 litro de hidróxido de cobre. A análise centesimal foi realizada nos grãos crus para verificar a qualidade físico-química dos mesmos. Os resultados obtidos demonstram que a solução é eficiente no controle da bacteriose assim como na melhoria do vigor vegetativo e produção, porém não interfere na qualidade do grão cru do café.

Termos para indexação: Bactericida, Coffea arabica, Pseudomonas syringae pv. garcae.

\section{INTRODUCTION}

Brazil stands out as the world's largest coffee producer and exporter, generating wealth and foreign exchange for the country, besides having a great social function. Exports historically represent more than half of foreign exchange earnings for $30 \%$ of the most important exporting countries and contributes with more than $25 \%$ to the value of total exports for the remaining $70 \%$ (JACOMINI; BACHA; FERRACIOLI, 2015). In Brazil, coffee represents $7 \%$ total exports of agricultural products, being the revenues of coffee crop quite significant in the southern region of Minas Gerais in relation to industry and commerce
(ARAUJO et al., 2008). The state of Minas Gerais accounts for the largest coffee growing and production park in Brazil, the South and Center-West regions of the state are highlighted in relation to the production of processed Arabica coffee (Coffea arabica) (VALE; CALDERARO; FAGUNDES, 2014).

The bacterial blight of coffee caused by the bacterium Pseudomonas syringae pv. garcae causes severe damage to Brazilian coffee cultivation, especially in coffee plants exposed to wind and cold and high-altitude coffee regions (ITO et al., 2008). It can be stated that bacterial blight of coffee does not have the same economic importance of coffee leaf rust, but it has become

${ }^{1}$ Federal Institute of Education, Science and Technology of the South of Minas Gerais - Campus Muzambinho - Department of Biology Estrada de Muzambinho, km 35- Bairro Morro Preto - Cx. P. 02 - 37.890-000 - Muzambinho - MG - barbosavip@hotmail.com ${ }^{2,3}$ Federal University of Lavras/UFLA - Department of Biology - Plant Physiology Sector - Cx. P. 3037 - 37.200-000 - Lavras - MG paulatsantini@gmail.com; guilherm@dcs.ufla.br 
limiting in colder regions exposed to wind, such as in the Brazilian states of Paraná, São Paulo and South of Minas Gerais, especially in young and pruned coffee plantations and in nurseries (GOMES et al., 2015).

Bacterial blight of coffee causes damage to leaves, rosettes, new fruits and branches. In the leaves, this bacterium causes necrotic lesions surrounded by yellowish halos. Such lesions are distributed throughout the leaf surface, being more frequent in the edges of leaves whereby the bacterium shows ease of penetration through lesions caused by mechanical damages (ITO et al., 2008). Moreover, it causes the drought of young branches and necrosis in rosettes and in new fruits. The new crops, from three to four years of age, are more affected, occurring defoliation, dieback, witch's broom and delay in the development of plants. However, in nurseries, the affected seedlings undergo defoliation and apical death, even leading to the plant death. The incidence of bacterial blight of coffee has been higher in crops at high altitudes, unprotected from winds and moderate cold (ANDREAZI et al., 2015).

The temperature and humidity that favor the disease are still being discussed. Bacterial blight of coffee generally begins in November and December, with the entry of cold periods. With wind and humidity, the disease can also be observed between May and July. (ITO et al., 2008). The bacterium is spread inside the plant and from plant to plant, by the action of rain splashes, light rain and wind (ZOCCOLI; TAKATSU; UESUGI, 2011).

The management of bacterial blight of coffee should be mainly preventive, through the installation of windbreaks, since it is an efficient, economic and ecologically correct method aimed to combat the entry of the disease in the crops and/or hamper its progress in affected areas (OLIVEIRA; OLIVEIRA; MOURA, 2012).

In chemical control, the use of copper compounds to control bacterial blight of coffee has been used due to its low cost to the producer, low environmental toxicity and relative efficacy (ITAKO et al., 2012). Currently, the chemical control used for seedlings consists of the application of kasugamycin hydrochloride intercalated with copper oxychloride, while products with copper salts as active principle have also been used in field conditions (CARVALHO; CUNHA; SILVA, 2012), which may not have good efficacy in the control.
The aim of the present study was to evaluate the efficiency of the bactericidal kasugamycin associated with copper hydroxide in the control of bacterial blight of coffee in young coffee plantations and to evaluate the influence on the physicochemical green coffee beans quality.

\section{MATERIAL AND METHODS}

The installation and the realization of the present experiment were performed in two distinct stages.

The first phase of the experiment was performed in a coffee plantation on São Domingos farm, Palméia neighborhood in Muzambinho, MG, Brazil, from August 2012 to July 2013. Muzambinho is in the South of Minas Gerais, at $21^{\circ} 22^{\prime} 00^{\prime \prime} \mathrm{S}, 46^{\circ} 31^{\prime} 00^{\prime}$ ' W and $1048 \mathrm{~m}$ altitude.

The used cultivar was Catucai $2 S L$ with four years old and spacing $3.0 \mathrm{~m}$ between lines and 0.8 $\mathrm{m}$ between plants; the used experimental design was in randomized blocks with five treatments, four replicates and plots composed by 10 plants in the field, where the treatments used different concentrations of the bactericidal kasugamycin: $0.0,250,500,750$ and $1000 \mathrm{~mL} \mathrm{ha}^{-1}$ added with $1.0 \mathrm{~L}$ copper hydroxide. Spraying was performed in August and November 2009, with application interval of 90 days.

The experiment was evaluated during the realization period through the following variables: productivity (bags $\mathrm{ha}^{-1}$ ), vegetative vigor and occurrence of bacterial blight of coffee. To evaluate the occurrence of bacterial blight of coffee, a scale proposed by Mohan, Cardoso and Paiva (1978) was modified, assigning grades from 1 to 5 , being: $1=$ plants without lesions; $2=$ few lesions in leaves with yellow halo, indicating bacterial blight of coffee development; 3 = many lesions on the leaves with yellowish halo, without dieback in the branches; $4=$ lesions in the leaves with yellow halo, with dieback of plagiotropic branches and/or orthotropic branches (from the tip up to five nodes towards the root); and $5=$ almost total dieback of the upper third of the plant. The vegetative vigor was evaluated based on the color of leaves, assigning grades from 1 to 5 , being: $1=$ yellowish leaf; 2 = light green; $3=$ medium green; $4=$ dark green; and $5=$ very dark green .

The second stage of the experiment was performed in the Laboratory of Bromatology of the Federal Institute of Education, Science and Technology of the South of Minas Gerais - Campus Muzambinho, from August to December 2013. 
During this stage, samples of green coffee beans were collected from the treatments cited above. The experimental design was in randomized blocks with five treatments $(0,250,500,750$ and $1000 \mathrm{~mL} \mathrm{ha}^{-1}$ kasugamycin).

The laboratory analysis followed the methodology of percent analyses: humidity (H) (ASSOCIATION OF OFFICIAL AGRICULTURAL CHEMISTS - AOAC, 1990); crude fiber (CF) (KAMER; GINKEL, 1952); crude protein (CP) (AOAC, 1990); ether extract (lipids) (EE) (AOAC, 1990); mineral residue or ash fraction (A) (AOAC, 1990); carbohydrate fraction $(\mathrm{CF})$ determined by equation: $\% \mathrm{CF}=$ $100-(\mathrm{H}+\mathrm{EE}+\mathrm{P}+\mathrm{F}+\mathrm{A})$; energy value used the Atwater conversion factors: $4 \mathrm{Kcal} / \mathrm{g}$ for proteins and carbohydrates, and $9 \mathrm{kcal} / \mathrm{g}$ for lipids (OSBORNE; VOOGT, 1978).

The control data of bacterial blight of coffee and quality of collected green beans were subjected to analysis of variance in order to verify significant differences among themselves and later analyzed by polynomial regression. Statistical analyses were performed using the SISVAR statistical software version 4.6 (FERREIRA, 2011).

\section{RESULTS AND DISCUSSION}

In Figures 1 and 2 can be verified that both the vegetative vigor and the productivity of the coffee plantation were influenced inasmuch as the kasugamycin concentrations were increased. These factors are related closely to plant health, adequate nutrient balance and availability of water resources, among other factors that influence the vegetative vigor of the plant (OLIVEIRA; OLIVEIRA; MOURA, 2012).

It is noteworthy that the isolated effect of kasugamycin and copper oxychloride on the control of the bacterial blight of passion fruit caused by the bacterium Xanthomonas campestris pv. passiflorae observed "early death", whereby copper oxychloride showed better results in the production (JUNQUEIRA et al., 2011). Oliveira et al. (2012) also proved greater efficiency in coffee plantations using cuprous oxide fungicide, resulting in higher productivity.

In the present study, a solution containing two products (kasugamycin and copper hydroxide) was tested. Therefore, it was not possible to evaluate the isolated effect of these products on the analyzed parameters, although the result allows suggesting that the association of both products influenced the increase of productivity and vegetative vigor.
It can be observed in Figure 03 that the intensity of bacterial blight of coffee decreased inasmuch as the kasugamycin concentrations decreased.

For the control of Xanthomonas campestris pv. passiflorae in passion fruit culture, copper oxychloride was more efficient than kasugamycin while tested separately (JUNQUEIRA et al., 2011). For the control of bacterial fruit blotch caused by Acidovorax avenae subsp. Citrulli which affects melon (Cucumis melo), the best control of the disease occurred with kasugamycin, especially when alternated with copper oxychloride applications (OLIVEIRA et al., 2012).

It is noteworthy that kasugamycin at a dosage of $500 \mathrm{mg} . \mathrm{L}^{-1}$ was very efficient to reduce populations of Pseudomonas syringae van Hall in kiwi (Actinidia chinensis Planch.), grape (Vitis spp.) and peach (Prunus persicae (L.) Batsch) according to Luisetti, Gaignard and Ride (1989).

The results obtained in the present study, based on the implemented conditions, are in agreement with the literature, in which kasugamycin is efficient in the control of bacterial blight in several cultures. Regarding the control of bacterial blight of coffee caused by Pseudomonas syringae pv. garcae Amaral, this active principle was significantly efficient (Figure 03), controlling the intensity of the disease in the crop and positively influencing the properties of vegetative vigor and productivity.

In Table 1, it is presented that there was no significant effect of the solution on the physical and chemical quality of the treated green coffee bean.

The values found in the percent analysis of the average of green bean treatments (Table 02) corroborate the averages found in the literature, demonstrating the quality of beans, as well as the beverage quality, which is extremely important for market acceptance, since the average values found in ether extract (lipids) are below the found average, which is $9 \%-16 \%$ (TSUKUI; OIGMAN; REZENDE, 2013). Therefore, the values of carbohydrate $(\mathrm{g})$ and energy (Kcal) are out of the average due to the conversion factor applied for the calculation, which considers the average values of the ether extract (lipids), according to the used methodology.

Thereby, it is understood that nothing can be stated on the influence of kasugamycin and copper hydroxide in the percent analysis, considering the time elapsed of harvesting, storage and laboratory analysis of approximately 12 months. 


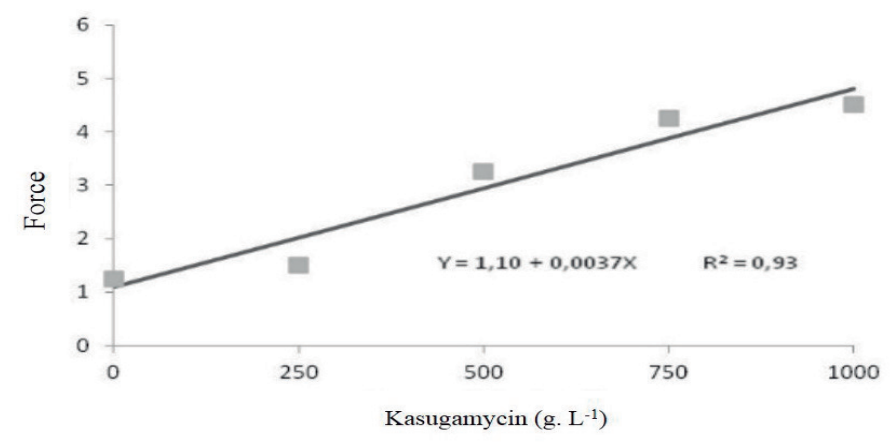

FIGURE 1 - Influence of kasugamycin on vegetative vigor of coffee plantation. Federal Institute of the South of Minas Gerais - Campus Muzambinho. Muzambinho, MG, Brazil. 2013.

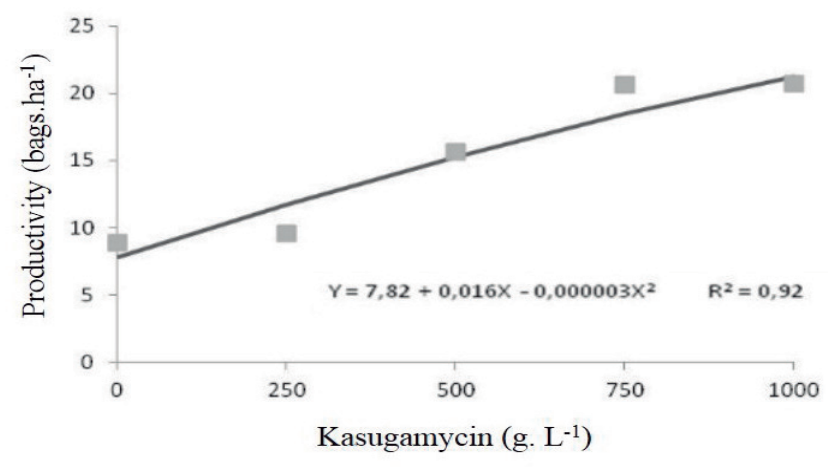

FIGURE 2 - Influence of kasugamycin on productivity of coffee plantation. Federal Institute of the South of Minas Gerais - Campus Muzambinho. Muzambinho, MG, Brazil. 2013.

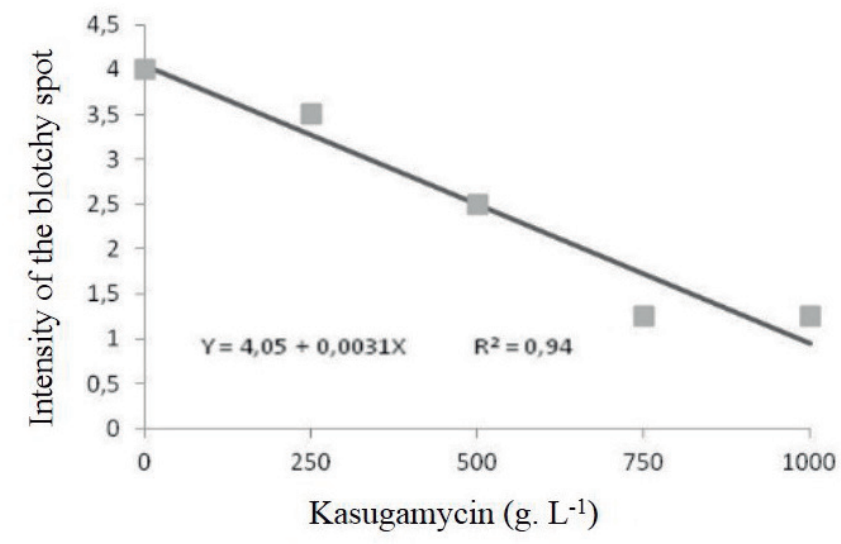

FIGURE 3 - Influence of kasugamycin on productivity of coffee plantation. Federal Institute of the South of Minas Gerais - Campus Muzambinho. Muzambinho, MG, Brazil. 2013. 
TABLE 1 - Physical and chemical analysis of green coffee bean treated with kasugamycin and copper hydroxide. Federal Institute of the South of Minas Gerais - Campus Muzambinho. Muzambinho, MG, Brazil. 2013.

\begin{tabular}{lcllccc}
\hline \multicolumn{7}{c}{ Mean square (MS) } \\
\hline Source of variation & GL & Moisture & Ash & $\begin{array}{c}\text { Crude } \\
\text { protein }\end{array}$ & $\begin{array}{c}\text { Ether } \\
\text { extract }\end{array}$ & Crude fiber \\
\hline Kasugamycin & 4 & $2.10 \mathrm{~ns}$ & $0.29 \mathrm{~ns}$ & $1.20 \mathrm{~ns}$ & $0.01 \mathrm{~ns}$ & $2.33 \mathrm{~ns}$ \\
Block & 3 & $2.67 \mathrm{~ns}$ & $15.82 \mathrm{~ns}$ & $0.60 \mathrm{~ns}$ & $2.47 \mathrm{~ns}$ & $0.82 \mathrm{~ns}$ \\
\hline $\mathrm{CV}(\%)$ & & 11.17 & 10.88 & 5.35 & 8.79 & 9.83 \\
\hline *ns Not significant by F test & & & & &
\end{tabular}

TABLE 2 - Averages of treatments of the green coffee bean Catucai 2SL in $100 \mathrm{~g}$ of sample. Federal Institute of the South of Minas Gerais - Campus Muzambinho. Muzambinho, MG, Brazil. 2013.

\begin{tabular}{ccccccc}
\hline Moisture & Mineral Matter & Crude Protein & Stereo Extract & Crude Fiber & Carbohydrates & Calorie Kcal \\
\hline 9,75 & 4,58 & 13,83 & 4,75 & 21,72 & 48,37 & 291,55 \\
\hline
\end{tabular}

In this respect, it should be noted that stored seeds undergo a deterioration process caused by irreversible degenerative changes, which can be mitigated through proper management of environmental conditions during the storage period (CARVALHO; ALMEIDA; GUIMARÃES, 2014). Otherwise, peroxidation reactions are initiated, which consists on the spontaneous generation of free radicals through auto-oxidation or catalysis by oxidative enzymes, which contribute to the seed deterioration in the storage period (COELHO et al. al., 2015).

It is relevant to consider that coffee quality is related directly to several physical and chemical constituents and the chemical composition of the green coffee bean, and it is influenced by preand post-harvest management conditions as well as related to genetic and environmental factors (ABRAHÃO et al., 2010).

\section{CONCLUSIONS}

It is concluded that the kasugamycin mixture associated with copper hydroxide raises the vegetative vigor and productivity of the coffee tree; is efficient in the control of the bacterial blight of coffee and does not affect the physical and chemical quality of the green coffee bean.

\section{ACKNOWLEDGEMENTS}

To the Foundation for Supporting Research of the State of Minas Gerais (FAPEMIG) for the granted scholarship.
To the IFSULDEMINAS - Campus Muzambinho for the laboratory structure provided for research.

\section{REFERENCES}

ABRAHÃO, S. A. et al. Compostos bioativos e atividade antioxidante do café (Coffea arabica L.). Ciência e Agrotecnologia, Lavras, v. 34, n. 2, p. 414420, mar./abr. 2010.

ANDREAZI, E. et al. Desempenho de híbridos F1 de café arábica com resistência simultânea a ferrugem, mancha aureolada e bicho mineiro. Coffee Science, Lavras, v. 10, n. 3, p. 375-382, jul./set. 2015.

ARAUJO, W. L. et al. Limitations to photosynthesis in coffee leaves from different canopy positions. Plant Physiology and Biochemistry, New Delhi, v. 46, n. 10, p. 884-890, 2008.

ASSOCIATION OF OFFICIAL AGRICULTURAL CHEMISTS. Official methods of the Association of the Agricultural Chemists. $15^{\text {th }}$ ed. Washington, DC, 1990. v. 2.

CARVALHO, C. A. M.; ALMEIDA, T. T.; GUIMARÃES, R. M. Plântulas de café originadas de sementes armazenadas e submetidas ao condicionamento fisiológico em matriz sólida. Nativa, Sinop, v. 2, n. 3, p. 166-169, set. 2014.

CARVALHO, V. C.; CUNHA, R. L.; SILVA, N. R. N. Alternativas de controle de doenças do cafeeiro. Coffee Science, Lavras, v. 7, n. 1, p. 42-49, abr. 2012. 
COELHO, S. V. B. et al. Alterações fisiológicas e bioquímicas em sementes de café secas em sílica gel e soluções salinas saturadas. Pesquisa Agropecuária Brasileira, Brasília, DF, v. 50, n. 6, p. 483-491, jun. 2015.

FERREIRA, D. F. Sisvar: a computer statistical analysis system. Ciência e Agrotecnologia, Lavras, v. 35, p. 1039-1042, 2011.

GOMES, C. A. et al. Seleção de Progênies do cruzamento entre cultivares de cafeeiros Icatu e Catuaí. Revista Ceres, Viçosa, v. 62, n. 1, p. 62-70, jan. 2015.

ITAKO, A. T. et al. Efeito de produtos químicos sobre a mancha bacteriana (Xanthomonas perforans) e na ativação de proteínas relacionadas à patogênese em tomateiro. Idesia, Arica, v. 30, n. 2, p. 85-92, ago. 2012.

ITO, D. S. et al. Resistance to bacterial blight in arabica coffee cultivars. Crop Breeding and Applied Biotechnology, Londrina, v. 8, p. 99-103, 2008.

JACOMINI, R.; BACHA, C. J. C.; FERRACIOLI, K. G. Comparação entre as políticas de café do Brasil e da Etiópia a partir de 1990. Revista de Política Agrícola, Brasília, DF, v. 1, p. 20-30, jan. 2015.

JUNQUEIRA, K. P. et al. Desempenho agronômico de maracujazeiros tratados com produtos alternativos e fertilizantes foliares. Revista Brasileira de Fruticultura, Jaboticabal, v. 33, n. 1, p. 40-47, mar. 2011.

KAMER, J. H.; GINKEL, L. Rapid determition of crude fiber in cereais. Cereal Chemistry, Saint Paul, v. 29, n. 4, p. 239-251, Aug. 1952.
LUISETTI, J.; GAIGNARD, J. L.; RIDE, M. Ability of kasumin to control some phytopathogenic bacteria. In: INTERNATIONAL CONFERENCE PLANT PATHOLOGY, 7., 1989, Budapest. Proceedings... Budapest, 1989. p. 213-218.

MOHAN, S. K.; CARDOSO, R. M. L.; PAIVA, M. A. Resistência em germoplasma de Coffea ao crestamento bacteriano incitado por Pseudomonas garcae. Pesquisa Agropecuária Brasileira, Brasília, DF, v. 13, n. 1, p. 53-64, 1978.

OLIVEIRA, I. P.; OLIVEIRA, L. C.; MOURA, C. S. F. T. Cultivo de café: pragas, doenças, correção do solo, adubação e consórcio. Revista Faculdade Montes Belos, São Luís de Montes Belos, v. 5, n. 4, p. 56-77, ago. 2012.

OLIVEIRA, J. C. et al. Caracterização de isolados de Acidovorax avenae subsp. Citrulli. Fitopatologia Brasileira, Brasília, DF, v. 32, n. 6, p. 480-487, 2012.

OSBORNE, D. R.; VOOGT, P. The analysis of nutrient in foods. London: Academic, 1978.

TSUKUI, A.; OIGMAN, S. S.; REZENDE, C. M. Óleo de grãos de café cru: diterpenos cafestol e caveol. Revista Virtual de Química, Niterói, v. 6, n. 1, p. 1633, 2013.

VALE, A. R.; CALDERARO, R. A. P.; FAGUNDES, F. N. A cafeicultura em Minas Gerais: estudo comparativo entre as regiões Triângulo Mineiro/Alto Paranaíba e Sul/ Sudoeste. Campo Território: Revista de Geografia Agrária, Francisco Beltrão, n. 2012, p. 1-23, jun. 2014. Edição especial.

ZOCCOLI, D. M.; TAKATSU, A.; UESUGI, C. H. Ocorrência de mancha aureolada em cafeeiros na região do Triângulo Mineiro e Alto da Paranaíba. Bragantia, Campinas, v. 70, n. 4, p. 843-849, 2011. 